Araştırma Makalesi
Adıaman Üniversitesi
Mühendislik Bilimleri Dergisi
$15(2021) 283-293$

\title{
INVESTIGATION OF POUNDING EFFECT IN MID-RISE ADJACENT STRUCTURES
}

\author{
Kabil ÇETİN ${ }^{*}$, Ali DEMIR ${ }^{2}$ \\ ${ }^{1}$ Manisa Celal Bayar University, Turgutlu Vocational School, Department of Construction, Manisa, 45400, Turkey \\ ${ }^{2}$ Manisa Celal Bayar University, Faculty of Engineering, Department of Civil Engineering, Manisa, 45140, Turkey \\ Geliş Tarihi/Received Date: 25.02.2021 Kabul Tarihi/Accepted Date: 08.09.2021 DOI: 10.54365/adyumbd.886805
}

\begin{abstract}
Many adjacent structures have been built in recent years due to population growth and the unplanned urbanization. The mass and stiffness differences of the structures cause collions with each other. Since behavior of structures having different dynamic properties will be different, the pounding forces occur between structures during earthquake. In this study, collision behavior in adjacent structures was investigated. The nonlinear spring Hertz model was used for modelling of collision. Existing structures were modeled with Sap 2000 program, by considering horizontal rigidity, story level and gap parameters as variables. Slab-column and slab-slab collision situations were taken into account in the structures. Dynamic analyses of the structures were performed by using Kocaeli earthquake data according to different gaps. Displacements and pounding forces of the structures were obtained and the results were compared. It was determined whether gaps calculated according to the Turkish Building Earthquake Code 2018 (TBEC-2018) were sufficient in the structures.
\end{abstract}

Keywords: Adjacent structures, Pounding force, Gap, Turkish Building Earthquake Code 2018, Dynamic analysis

\section{ORTA YÜKSEKLİKTEKİ BİTIŞİK NIZZM YAPILARDA ÇEKIÇLEME ETKISINININ INCELENMESI}

\section{ÖZET}

Nüfus artışı ve çarpık kentleşme nedeniyle son yıllarda birçok bitişik nizam yapı inşa edilmiştir. Yapıların kütle ve rijitlik farklılıkları birbirleriyle çarpışmasına neden olur. Farklı dinamik özelliklere sahip yapıların davranışları farklı olacağından yapılar arasında deprem esnasında çekiçleme kuvvetleri oluşur. Bu çalışmada, bitişik nizam yapılarda çarpışma davranışı araştırılmıştır. Lineer olmayan Hertz yay modeli çarpışmanın modellenmesi için kullanılmıştır. Mevcut yapılar, değişken olarak yatay rijitlik, kat seviyesi ve derz boşluğu parametreleri dikkate alınarak Sap 2000 programı ile modellenmiştir. Yapılarda döşeme-kolon ve döşemedöşeme çarpışma durumları dikkate alınmıştır. Farklı derz boşluklarına göre Kocaeli deprem verileri kullanılarak yapıların dinamik analizleri yapılmıştır. Yapıların yer değiştirmeleri ve çekiçleme kuvvetleri elde edilmiş ve sonuçlar karşılaştırılmıştır. Türkiye Bina Deprem Yönetmeliği 2018'e (TBDY-2018) göre hesaplanan derz boşluklarının yapılarda yeterli olup olmadığı belirlenmiştir.

Anahtar Kelimeler: Bitişik nizam yapılar, Çekiçleme kuvveti, Derz boşluğu, Türkiye Bina Deprem Yönetmeliği 2018, Dinamik analiz.

\footnotetext{
*e-mail: cetinkabil@gmail.com ORCID ID: https://orcid.org/0000-0001-9236-3447 (Sorumlu Yazar), e-mail: ali.demir@,cbu.edu.tr ORCID ID:https://orcid.org/0000-0001-9907-4074
} 


\section{Introduction}

The devastating effect of earthquakes is always a significant threat for both people and structures. The speed of urbanization has considerably increased in recent years. As a result, the structures have been built as adjacent. Structures make large displacements under the earthquake effect. The dimension of displacement in the structure depends on many factors such as the mass, rigidity of the structure. Different displacements of adjacent structures having different dynamic characteristics cause collision with one another. In the literature, this effect is called pounding. This effect which is called as pounding results from insufficient gap between adjacent structures. The pounding force also affects the earthquake behaviour of the structure. Collision could cause regional damages in the structural elements or collapse. Studies carried out by the researchers revealed that this effect should be considered.

Hao [1] modeled 5 and 10 storey structures. The pounding forces, displacements and shear forces of the structures were compared according to different gaps and local soil classes. The increase in shear force is more important in the light structure. The collision was seen to have little effect on story shear force results for different local soil classes. Noman et al [2] investigated the minimum size of gap required for mid-rise structures. Adjacent structures with different geometry and height were modeled. Pushover and inelastic time history analyses of structures were performed. Column shear forces and maximum displacements were investigated. The collision occurred up to a gap of 6 inches. It was modeled two 6 storey structures with equal story levels. By changing the dimensions of the ground floor columns in one of the structures, weak story irregularity was created in the structure. The time history analyses of the structures were carried out. It was concluded that the irregularity in the structure generally increased the pounding force. As a result of the irregularity, it was observed that the collision occurred on all stories of the structure [3]. Collision behaviors of the structures were investigated. Structure types having different rigidities were modeled. By placing rubber material between the adjacent structures, the effect of this new situation on the pounding force was investigated and the results were compared. Pounding forces significantly increased in structures with different story levels compared to structures with equal story levels. It was concluded that this material reduced pounding force by approximately 55\% [4]. Inel et al [5] investigated the effect of pounding on earthquake behavior in mid-rise reinforced concrete structures with insufficient gap size. 4 and 7 storey structure models built according to the 1975 and 1998 Turkish Seismic Code were used. The nonlinear time history analyses of the structures were performed according to different earthquake records. To evaluate the effect of the collision, the pounding force and the number of collisions occurring on the critical story were investigated. The pounding force increased roof displacements. It was said that the pounding force could cause permanent displacements in the free direction of the structure. Aydin et al [6] investigated the effect of passive viscous dampeners used in adjacent structures on the pounding force. Two adjacent structures were modeled as 20 and 10 storey. Dampers were placed between the structures in two different ways. For the first case, a single damper was placed at the 10th story level of the structure. In the second case, the damper was placed from the 1st story level to the 10th story level. However, the damper's damping coefficients in the second case were reduced by 10 times compared to the first case. Time history analysis was performed by using El Centro earthquake. Relative story displacements of the structures were compared for two different cases. Relative story displacements decreased significantly with the use of dampers. Thus, the occurrence of pounding effects between adjacent structures can be prevented. The performance of the dampers for both cases was approximately equal in terms of relative story displacement. It was said that the use of single damper would be more beneficial for reasons such as economy, maintenance and inspection. Aydin et al [7] investigated the calculation of optimum viscous dampeners to be placed between adjacent structures to prevent pounding effects. The optimum design under the earthquake loads was tested with an algorithm. Time history analyses were carried out by using El Centro earthquake record. 4 storey adjacent shear frames were modeled and proposed method was used. The effect of damper on structural behavior was demonstrated. The validity of the proposed method was proven. Aydin et al [8] formed the mechanical model of adjacent structures as a two single degree of freedom system. The rigidity of one of the structures was changed 
while the other was kept constant. Time history analyses were performed by using El Centro earthquake data for different period ratios. The maximum relative displacements of the structures were obtained. Relative displacement response spectra graphs were plotted. Damper was placed between adjacent structures. The relative displacement response spectra obtained from as with damper and without dampers were compared. The dampers were seen to be extremely effective in preventing the pounding effect. Karabulut et al [9] modeled two adjacent structures with 4 and 6 storeys. Analyses were carried out using İzmit earthquake data linearly. Time-dependent deformation results were obtained in structures for different gaps. The gap required according to the Turkish Earthquake Code in order to prevent the pounding effect was compared with the results. Pala and Şaşmaz [10] investigated the effect of adjacent structures with different storey levels on the pounding force. Two 4-storey structures were modeled. Slab-column collision situations occurred in the structures. Dynamic analyses were carried out according to different slab thickness and gap. El Centro earthquake data were used in the analyses. The maximum pounding force values were obtained. The displacement values between the points where this force occurs were presented. It was said that the structure columns will be subjected to a maximum pounding force of $1360 \mathrm{kN}$. It was emphasized that the gap is very important for adjacent structures. Tekin and Pala [11] modeled two 6-storey structures with the same storey heights. The B3 irregularity was created by removing the columns in the structures. Dynamic analyses were carried out by using El Centro earthquake data according to different gaps. Maximum pounding forces and displacement values were obtained for cases with and without B3 irregularity. The irregularity increased the pounding force. According to the Turkish Earthquake Code 2007, pounding force was seen for the minimum gap of 7 $\mathrm{cm}$. It was said that the gap should be increased in adjacent structures with irregularities.

In this study, existing two structures with different rigidity have been modeled. Time history analyses have been performed linearly by using Kocaeli earthquake accelerogram. The collision between structures has been defined by the nonlinear Hertz spring model. Storey heights and gaps in structures have been considered as variables. Displacements and pounding forces occurring in the structures have been presented. The sufficiency of the gap calculated according to the TBEC-2018 has been checked.

\section{Material and Method}

\subsection{Collision Model}

The collision between adjacent structures has been defined by using the Hertz spring model. Force transfer will start with a nonlinear spring as soon as contact between structures occurs. The interaction between the adjacent structures has been described as gap element in Sap 2000. Therefore, when the gap between the two structures is closed, contact will occur between the structures and pounding forces will occur. The Hertz spring model is designed as an analytical model without axial stiffness up to a certain distance. However, it detects the predicted stiffness after a certain displacement level. In this case, the spring model produces a compression force when the gap closes. The formation of the pounding force is stated in the equation 1 [12].

$$
f_{G}(t)=\left\{\begin{array}{cc}
k_{G}[u(t)-d]^{3 / 2} & u(t)-d>0 \\
0 & u(t)-d \leq 0
\end{array}\right\}
$$

$u_{i}(t)$ and $u_{j}(t)$ are time-dependent displacements of adjacent structures in the same earthquake direction, respectively. $u(t)$ is described as $u_{i}(t)-u_{j}(t) . k_{G}$ is the elastic spring rigidity in the gap element. $d$ is the initial size of gap between structures [12]. $\mathrm{k}_{\mathrm{G}}$ value is determined as $1.13 \times 10^{9} \mathrm{~N} / \mathrm{m}^{3 / 2}$ by Jankowski. Based on experimental studies, it is recommended that this value should be used in 
concrete-concrete collisions [13]. The relationship between displacement and pounding force in the spring model is shown in Figure 1 [14].

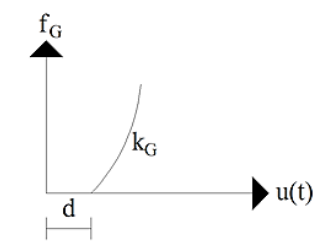

Figure 1. Pounding force-displacement relationship in the Hertz spring model

\subsection{Numerical Example}

As numerical example, existing two 4 storey structures have been modeled to investigate the pounding effect in the structures by using Sap 2000 program. Structure models used in the study are given in Figure 2.



Figure 2. Models of structures

It is seen that both models have frame load-bearing system, same plan geometry and column layout. The difference between structures is the column sizes. Structures with different dynamic properties make different displacements during an earthquake. Collision occurs due to insufficient or lack of gap between structures. Hence, modeled the structures have different mass and rigidity. This rigidity difference between the structures is created by changing the column sizes. Model 1 and Model 2 are named as rigid structure and elastic structure, respectively. Column sizes in the structures are given in Table 1 .

Table 1. Column types and sizes

\begin{tabular}{lcc}
\hline \multicolumn{3}{c}{ Sizes of Columns (cm) } \\
\hline Types of Columns & $\begin{array}{c}\text { Model 1 } \\
\text { (Rigid Structure) }\end{array}$ & $\begin{array}{c}\text { Model 2 } \\
\text { (Elastic Structure) }\end{array}$ \\
\hline Corner Column & $50 \times 50$ & $35 \times 35$ \\
\hline Edge Column & $30 \times 50$ & $30 \times 40$ \\
\hline Center Column & $40 \times 40$ & $30 \times 30$ \\
\hline
\end{tabular}

Dimensions of spans in the $\mathrm{x}$ and $\mathrm{y}$ directions are $5 \mathrm{~m}$ and $3 \mathrm{~m}$, respectively. Beam sizes are $25 \times 50$ $\mathrm{cm}$. C25 concrete class and S420 steel material have been used. The elasticity modulus and unit volume weight of the concrete are $31 \times 10^{6} \mathrm{kN} / \mathrm{m}^{2}$ and $25 \mathrm{kN} / \mathrm{m}^{3}$ respectively. Structures have been modeled according to TBEC-2018. Effective cross-section stiffness multipliers have been used modeling of the structural members. Dynamic analyses have been performed for two different cases. In collision model A, story heights of adjacent structures have been assumed to be equal and $3 \mathrm{~m}$. So, collision have 
occurred at story level. In collision model B, story height of the model 1 has been changed as $3.5 \mathrm{~m}$. So, collision have occurred at different level of story. Collision models of structures are shown in Figure 3. Thus results have been obtained for slab-column and slab-slab collision cases.

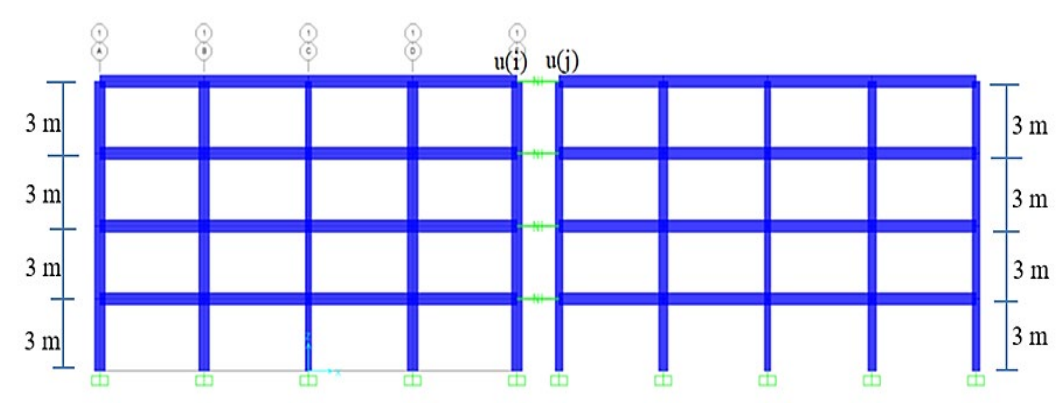

a) Collision model $\mathrm{A}$

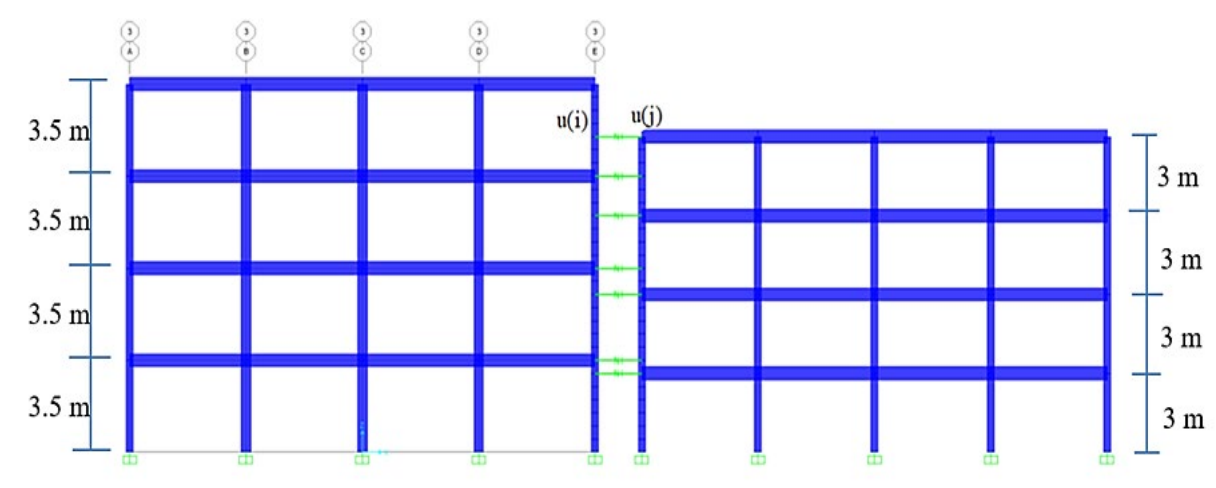

b) Collision model B

Figure 3. Collision models of the structures $(a, b)$

Collision effects between adjacent structures are represented by Hertz springs. Hertz springs are shown in Figure 3 with green lines. The Hertz spring model defined as the gap element is presented in Figure 4 [15].

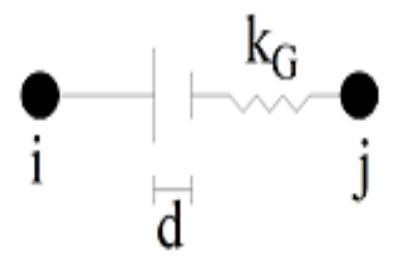

Figure 4. Hertz spring model

Time history analyses have been performed linearly by using Kocaeli earthquake east-west (EW) component data according to different gaps. The coordinates of the earthquake station are 40.84364 latitude and 31.14888 longitude. Peak ground acceleration is 0.381 g. Accelerogram of Kocaeli earthquake is presented in Figure 5. 




Figure 5. Accelerogram of Kocaeli earthquake

\section{Results and Discussions}

The pounding forces and displacement values of the existing structures have been determined after the dynamic analyses have been carried out by taking into account Kocaeli earthquake records. Pounding forces and displacement values at collision points have been obtained for different gaps. The numbers of collisions, time and collision levels change according to the mass of structure and gap between structures. Pounding forces for collision models A and B are given in Figures 6 and 7.

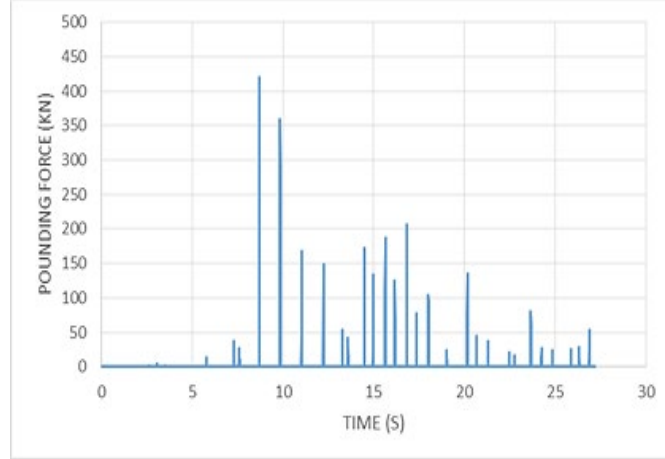

a) $0 \mathrm{~cm}$



b) $1 \mathrm{~cm}$

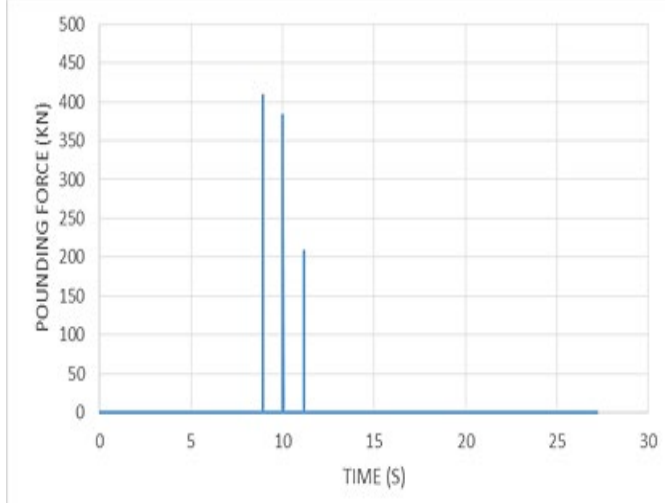

c) $2 \mathrm{~cm}$

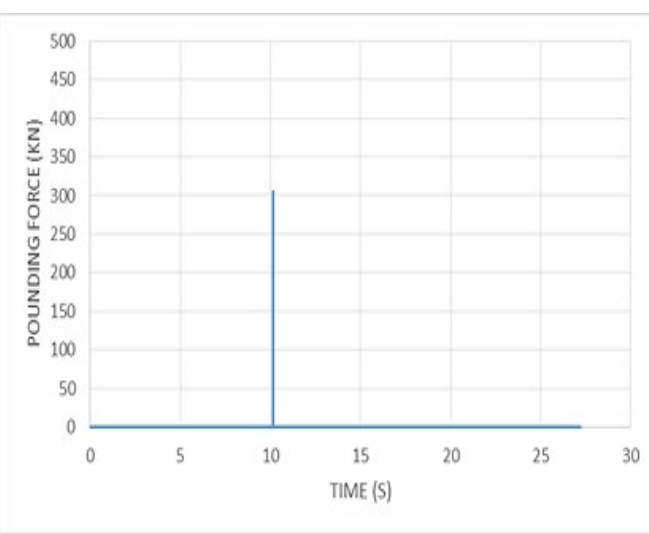

d) $3 \mathrm{~cm}$

Figure 6. Maximum pounding forces according to different gaps (Collision model A) 


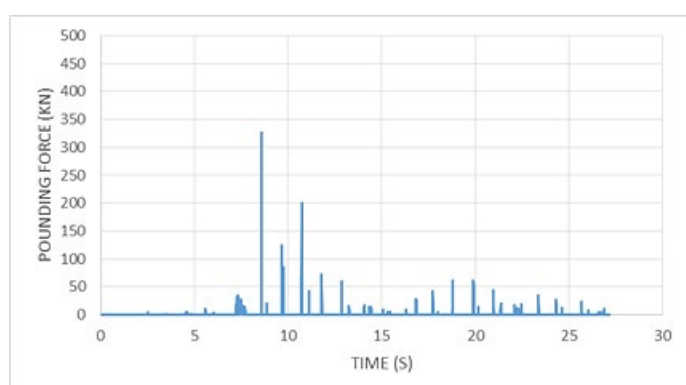

a) $0 \mathrm{~cm}$

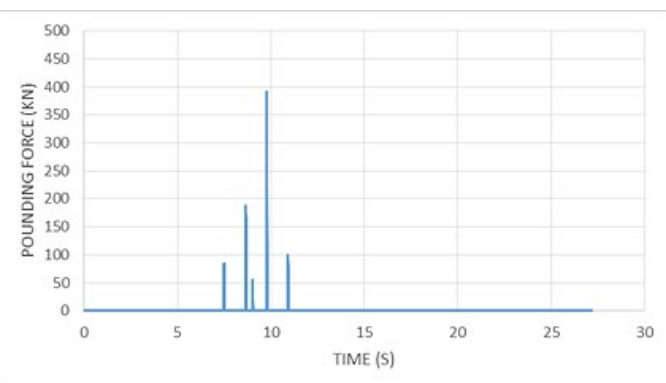

b) $1 \mathrm{~cm}$

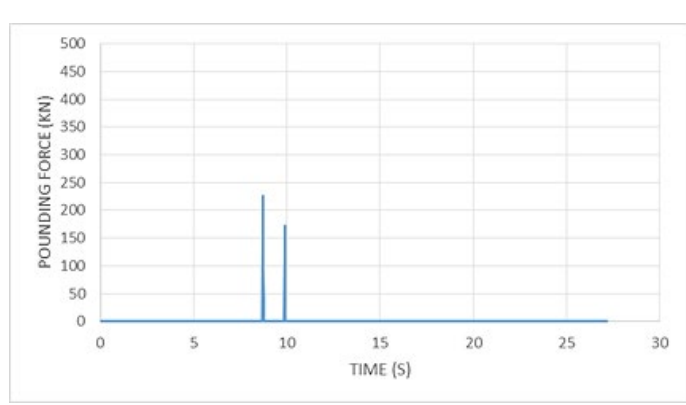

c) $2 \mathrm{~cm}$

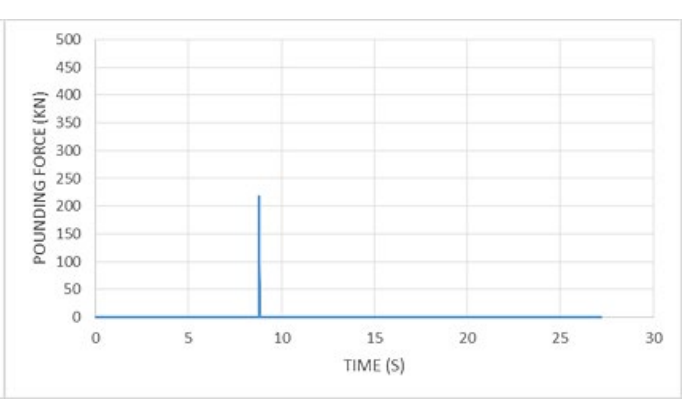

d) $3 \mathrm{~cm}$

Figure 7. Maximum pounding forces according to different gaps (Collision model B)

Minimum gap is to be up to $6 \mathrm{~m}$ height at least $30 \mathrm{~mm}$ according to TBEC-2018. At least $10 \mathrm{~mm}$ must be added to this value for every $3 \mathrm{~m}$ height after $6 \mathrm{~m}$ [16]. According to the TBEC-2018, the minimum gap of existing structures is $5 \mathrm{~cm}$. It is not given pounding force graphs for $4 \mathrm{~cm}$ and $5 \mathrm{~cm}$ gaps in Figures 6 and 7. Since collision in these gaps hasn't occurred. If the structures are adjacent (0 $\mathrm{cm}$ ), force transfer occurs in all springs. As the gap increases, the number of collisions decreases. The pounding forces of collision model A are greater than collision model B. The locations where maximum pounding forces occur in Figures 6 and 7 are given in Table 2.

Table 2. Location and time of the maximum pounding force for collision models A and B according to different gaps under Kocaeli (E-W) ground motion

\begin{tabular}{|c|c|c|c|c|}
\hline & \multicolumn{2}{|c|}{ Collision Model A } & \multicolumn{2}{|l|}{ Collision Model B } \\
\hline $\begin{array}{l}\text { Gap } \\
\text { (cm) }\end{array}$ & $\begin{array}{c}\text { Location of Maximum } \\
\text { Pounding }\end{array}$ & $\begin{array}{c}\text { Time } \\
(s)\end{array}$ & $\begin{array}{l}\text { Location of Maximum } \\
\text { Pounding }\end{array}$ & $\begin{array}{c}\text { Time } \\
\text { (s) }\end{array}$ \\
\hline 0 & 3rd Story Level & 8.71 & $\begin{array}{c}\text { 3rd Story Level Of The Elastic } \\
\text { Structure }\end{array}$ & 8.585 \\
\hline 1 & 3rd Story Level & 8.805 & $\begin{array}{l}\text { 4th Story Level Of The Elastic } \\
\text { Structure }\end{array}$ & 9.785 \\
\hline 2 & 4th Story Level & 8.91 & $\begin{array}{l}\text { 4th Story Level Of The Elastic } \\
\text { Structure }\end{array}$ & 8.71 \\
\hline 3 & 4th Story Level & 10.16 & $\begin{array}{l}\text { 4th Story Level Of The Elastic } \\
\text { Structure }\end{array}$ & 8.8 \\
\hline
\end{tabular}

In Table 2, the collision occurs at a later time since the gap increases. The collisions generally occur at the last two stories levels of the elastic structure. For $0 \mathrm{~cm}$ gap, collision have occurred at all story levels in collision models A and B. For $1 \mathrm{~cm}$ and $2 \mathrm{~cm}$ gaps, collision has occurred only at the 3rd and 4th story levels in collision model A. In collision model B, collision has occurred for $1 \mathrm{~cm}$ and 2 
$\mathrm{cm}$ gaps, at every point between the 2nd story level of the rigid structure and the 4th story level of the elastic structure. For the $3 \mathrm{~cm}$ gap, structures have collided only at 4 th story level of the elastic structure in collision models A and B. The maximum pounding force values obtained for each gap are given in Figure 8.

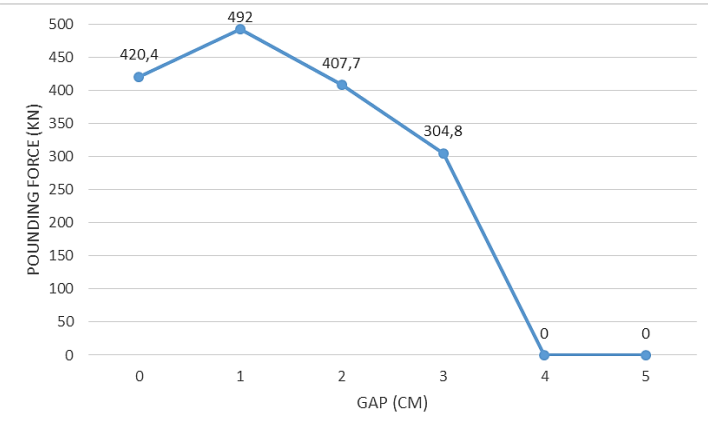

a) Collision model $\mathrm{A}$

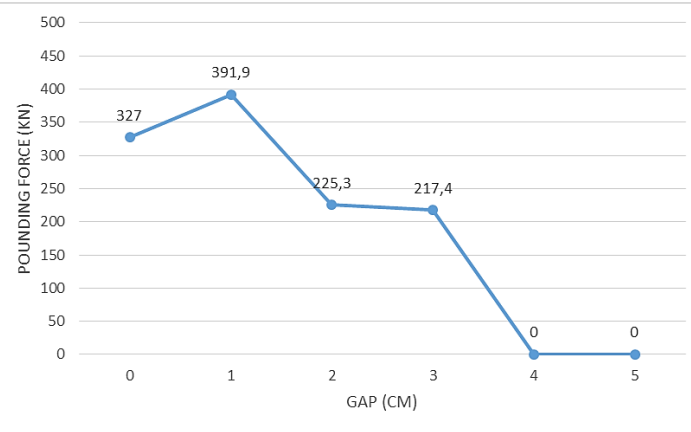

b) Collision model B

Figure 8. Change of maximum pounding forces according to different gaps $(\mathrm{a}, \mathrm{b})$

The pounding force decreases as the gap increases as shown in Figure 8. Structures do not collide for $4 \mathrm{~cm}$ and $5 \mathrm{~cm}$ gaps in both collision models A and B. The displacement values at the point occurred of maximum pounding force is presented in Figures 9 and 10.

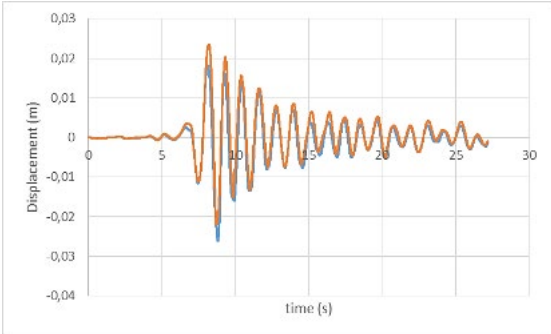

a) $0 \mathrm{~cm}$



c) $2 \mathrm{~cm}$



e) $4 \mathrm{~cm}$



b) $1 \mathrm{~cm}$

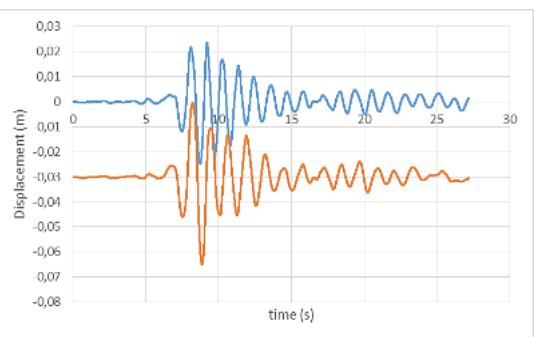

d) $3 \mathrm{~cm}$

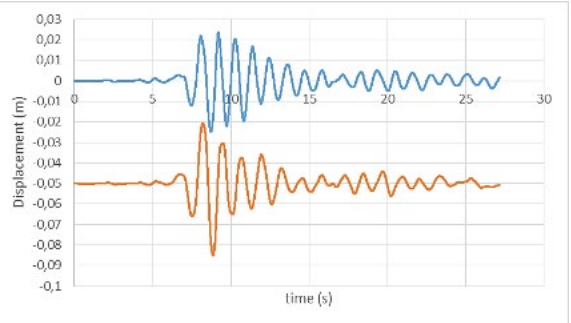

f) $5 \mathrm{~cm}$

Figure 9. Time-dependent change of displacement for collision model A 




a) $0 \mathrm{~cm}$

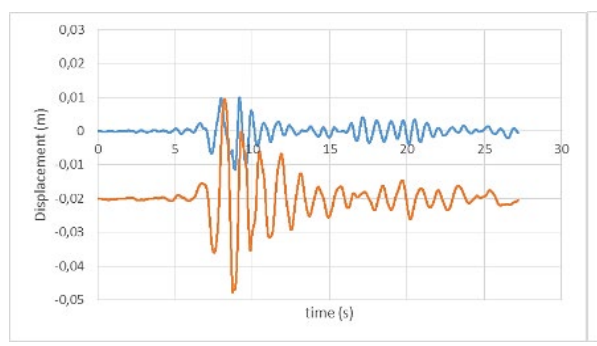

c) $2 \mathrm{~cm}$

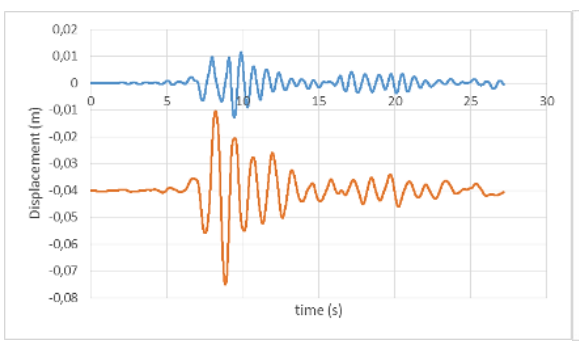

e) $4 \mathrm{~cm}$

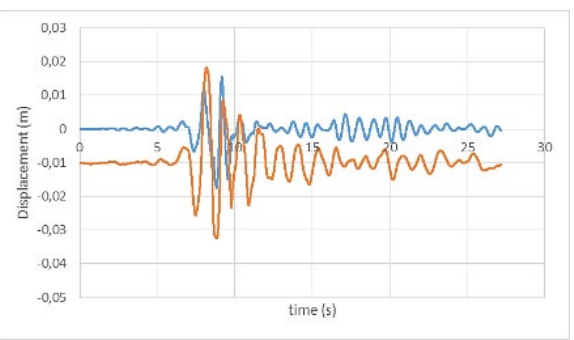

b) $1 \mathrm{~cm}$



d) $3 \mathrm{~cm}$



f) $5 \mathrm{~cm}$

Figure 10. Time-dependent change of displacement for collision model B

In Figures 9 and 10, the orange line represents the elastic structure, while the blue line represents the rigid structure. Graphs obtained for $4 \mathrm{~cm}$ and $5 \mathrm{~cm}$ gaps are same in collision model A. Because the structures do not collide. Likewise, it is seen that the graphics are the same for $4 \mathrm{~cm}$ and $5 \mathrm{~cm}$ gaps in the collision model B. The displacement values of the rigid and elastic structure in collision model A are larger than in collision model B. In both collision models A and B with gaps of $2 \mathrm{~cm}$ and above, collisions have occurred at the same story levels. Therefore, the displacement values of the elastic structure in collision models A and B are close to each other for these gaps. However, it is clearly seen that there is a collision risk in the structures for $4 \mathrm{~cm}$ gap in both collision models. For $5 \mathrm{~cm}$ gap, this risk has occurred only in the collision model $\mathrm{A}$. Therefore, gap has been increased and the displacement results of the existing two structures have been obtained for $6 \mathrm{~cm}$. The results are presented in Figure 11. 




a) Collision model $\mathrm{A}$

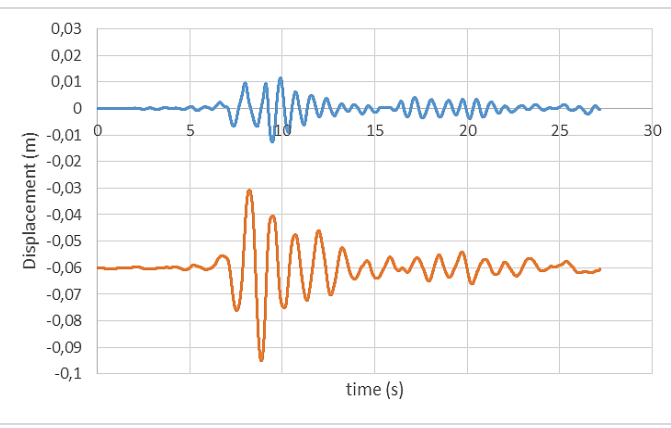

b) Collision model B

Figure 11. Time-dependent change of displacement according to $6 \mathrm{~cm}$ gap $(\mathrm{a}, \mathrm{b})$

It has been determined that $6 \mathrm{~cm}$ gap is suitable for both collision models. When the $6 \mathrm{~cm}$ gap is selected, the structures in both collision models will not be subjected to pounding against a possible earthquake threat. The maximum displacement values at point occurred of the maximum pounding force are presented in Table 3.

Table 3. Maximum displacement values for collision models A and B according to different gaps under Kocaeli (E-W) ground motion

\begin{tabular}{lcccc}
\hline & \multicolumn{2}{c}{ Collision model A } & \multicolumn{2}{c}{ Collision model B } \\
\hline Gap & $\begin{array}{c}\text { Rigid Structure } \\
(\mathbf{m})\end{array}$ & $\begin{array}{c}\text { Elastic Structure } \\
(\mathbf{m})\end{array}$ & $\begin{array}{c}\text { Rigid Structure } \\
(\mathbf{m})\end{array}$ & $\begin{array}{c}\text { Elastic Structure } \\
(\mathbf{m})\end{array}$ \\
\hline 0 & 0.02159 & 0.02359 & 0.01674 & 0.02157 \\
\hline 1 & 0.02009 & 0.02861 & 0.01757 & 0.02826 \\
\hline 2 & 0.02481 & 0.03504 & 0.01142 & 0.03257 \\
\hline 3 & 0.02481 & 0.03578 & 0.00966 & 0.03341 \\
\hline
\end{tabular}

Maximum displacement values are given for the gap where the collisions occur in Table 3. If these results for collision model B are investigated, the rigid structure displacements are similar to the maximum pounding force diagram in Figure 8.b. Displacement values increase and decrease depending on the magnitude of pounding forces. As the gap increases, the displacement values of the elastic structure increase in both collision models.

\section{Conclusions}

It has been seen that the minimum gap calculated according to TBEC-2018 is sufficient in terms of structures. The number, time and force of collisions change according to gaps. For different gaps, maximum pounding forces have occurred at different story levels. For $1 \mathrm{~cm}, 2 \mathrm{~cm}$ and $3 \mathrm{~cm}$ gaps, collisions have occurred in one or two stories of the structures. If the structures are adjacent, the collision occurs on all stories. As the gap increases, pounding forces decrease. For the Kocaeli earthquake, collisions have not occurred in the structures, especially in gaps of $4 \mathrm{~cm}$ and above. However, there is a collision risk of structures for these gaps. It has been determined that this risk will not exist in both models for $6 \mathrm{~cm}$ gap. When the gap is $6 \mathrm{~cm}$, it is concluded that the structures cannot be damaged due to pounding. Slab-slab and slab-column collisions have occurred for two different collision models. In both cases, it is seen that large amounts of pounding forces for insufficient gaps can affect structures and even cause serious damage to structures. When the gap between the structures is below $4 \mathrm{~cm}$, pounding forces of about $500 \mathrm{kN}$ and $400 \mathrm{kN}$ are obtained in collision model A and collision model $\mathrm{B}$, 
respectively. Therefore, in terms of structural safety of adjacent structures, it is necessary to construct the structures in accordance with the minimum gaps stipulated in the TBEC-2018 at worst.

\section{References}

[1] Hao H. Analysis of seismic pounding between adjacent buildings. Australian Journal of Structural Engineering 2015; 16: 208-225.

[2] Noman M, Alam B, Fahad M, Shahzada K, Kamal M. Effects of pounding on adjacent buildings of varying heights during earthquake in Pakistan. Cogent Engineering 2016; 3: 1-19.

[3] Tekin ÖF, Pala M. Collision analysis earthquake exposed adjacent structure which has weak storey irregularities. Academic Platform Journal of Engineering and Science 2017; 5: 23-33.

[4] Özkaynak H, Güler S. Reduction of seismic collision effect in reinforced concrete structure. In: 1st International Congress on Engineering and Architecture, Alanya, Turkey; 2018.

[5] Inel M, Caycı BT, Kamal M, Altınel O. Structural pounding of mid-rise rc buildings during earthquakes. In: 2nd European Conference on Earthquake Engineering and Seismology, Istanbul, Turkey; 2014.

[6] Aydin E, Ozturk B, Cetin H, Simsek T. Application of viscous dampers for prevention of pounding in adjacent reinforced concrete buildings. In: 16th World Conference on Earthquake Engineering, Santiago, Chile; 2017.

[7] Aydin E, Ozturk B, Dikmen M. Optimal damper placement to prevent pounding of adjacent structures considering a target damping ratio and relative displacement. Omer Halisdemir University Journal of Engineering Sciences 2017; 6: 581-592.

[8] Aydin E, Ozturk B, Yesil L. Application of viscous dampers for prevention of pounding effect in adjacent buildings. In: 14th European Conference on Earthquake Engineering, Ohrid, Republic of Macedonia; 2010.

[9] Karabulut M, Kartal ME, Özil E, Ünlü R. Investigation of earthquake joint pavement in reinforced concrete buildings. Natural \& Applied Sciences Journal 2018; 1: 39-45.

[10] Pala M, Şaşmaz Z. The effect of floor mass on the collision strength in different adjacent structures with different storey levels. Journal of Engineering Science of Adıyaman University 2019; 10: 265281.

[11] Tekin ÖF, Pala M. Effect of vertical element discontinuity on structure during seismic collision in load-bearing system. In: 4th International Symposium on Innovative Technologies in Engineering and Science, Pecs, Hungary; 2016.

[12] Dertli HH, Sunca F, Akkose M. Pounding response between rc buildings with equal heights and different dynamic characteristics considering seismic zone 1 of Turkey. Nevsehir Journal of Science and Technolog 2017; 6:362-370.

[13] Jankowski R. Non-linear viscoelastic modelling of earth-quake-induced structural pounding. Earthquake Engineering and Structural Dynamics 2005; 34: 595-611.

[14] Muthukumar S, DesRoches R. A hertz contact model with non-linear damping for pounding simulation. Earthquake Engineering and Structural Dynamics 2006; 35: 811-828.

[15] Computer and Structures Inc. SAP2000: Integrated finite element analysis and design of structures. California: Computers and Structures; 1998.

[16] Disaster and Emergency Management Presidency of Turkey. Turkish Building Earthquake Code. 2018. 